\title{
Church and State in Ireland (1922-2013): Contrasting Perceptions of Humanity
}

\section{Catherine Maignant}

\section{(2) OpenEdition \\ 1 Journals}

\section{Electronic version}

URL: https://journals.openedition.org/etudesirlandaises/3913

DOI: 10.4000/etudesirlandaises.3913

ISSN: 2259-8863

\section{Publisher}

Presses universitaires de Caen

\section{Printed version}

Date of publication: 20 November 2014

Number of pages: 63-77

ISBN: 978-2-7535-3559-6

ISSN: 0183-973X

\section{Electronic reference}

Catherine Maignant, "Church and State in Ireland (1922-2013): Contrasting Perceptions of Humanity", Études irlandaises [Online], 39-2 | 2014, Online since 20 November 2016, connection on 21 September 2021. URL: http://journals.openedition.org/etudesirlandaises/3913 ; DOI: https://doi.org/10.4000/ etudesirlandaises.3913

This text was automatically generated on 21 September 2021.

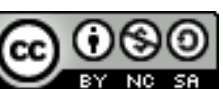

Études irlandaises est mise à disposition selon les termes de la Licence Creative Commons Attribution - Pas d'Utilisation Commerciale - Partage dans les Mêmes Conditions 4.0 International. 


\title{
Church and State in Ireland (1922-2013): Contrasting Perceptions of Humanity
}

\author{
Catherine Maignant
}

1 Even though Enda Kenny, a practising Catholic, has repeatedly ruled out abortion on demand, his Protection of Life during Pregnancy Act ${ }^{1}$ is a turning point in the history of Ireland. When Savita Halappanavar died after being denied an abortion even though she was miscarrying in October 2012, her husband was told that the explanation lay in Ireland being a Catholic country. Yet the issue arose as Church State relations had reached an all time-low following revelations of child abuse in religious institutions and attempts of cover up on the part of the Church. It also came after three women challenged the Irish State's abortion laws at the European Court of Human Rights on grounds that they contravened the international right to be "free from cruel, inhuman and degrading treatment $t^{2}$. But inhumanity is a matter of interpretation, as is the fight for life. Contrasting understandings of humanity, inhumanity and morality have informed the political debate in Ireland since the creation of the Irish Free State. Using these as a starting point and examining them both in historical and international perspectives, this paper will argue that they may be a key to interpret the history of Church-State relations in Ireland since 1922.

\section{The abortion issue and the question of human rights in Irish law}

2 Writing in 1984, the year after the abortion referendum, Desmond Clarke presented the Irish State as "confessional rather than pluralist; timid and reluctant about individual freedoms; favouring censorship rather than freedom of thought and speech; and overly concerned about its perceived role as a civil handmaid to the theological demands of an infallible church". In his estimation however, the creative approach of Irish courts to the 
constitution was an "encouraging sign in the history of human rights in Ireland". Thanks to this attitude, he argued, they guaranteed "more rights to citizens than those who wrote it might ever have imagined". Whenever Irish courts were unable or unwilling to intervene, the European Court of Human Rights did, which allowed Clarke to conclude: "The frequency with which the courts have intervened to correct the Oireachtas' perception of the common good and to modify it in defence of individual rights is a convincing argument in favour of the need for constitutional limits to the legislative power of governments4." Whether or not one agrees with this opinion, Clarke had a point when he noted that "the recognition and defence of human rights [was] almost exclusively due to the courts 5 ".

3 It is significant in that respect that Enda Kenny's government should have decided to legislate on the basis of the $1992 \mathrm{X}$ case decision of the Supreme Court ${ }^{6}$. That it should have taken twenty years and the death of a woman is also significant, as is the fact that a heated debate has ensued, even if no liberalization of abortion was ever on the agenda. What was at stake was merely the clarification of the existing law as regarded the circumstances in which a pregnant woman whose life was threatened might have an abortion in Ireland, including the case when she had suicidal thoughts. Yet in their statement of December 2012, the four archbishops of Ireland dismissed the 1992 Supreme Court ruling as a "flawed judgment" and expressed their concern at the government's intention to introduce new legislation, on grounds that "the dignity of the human person and the common good of humanity depend on our respect of the right to life of every person from the moment of conception to natural death. The right to life is the most fundamental of all rights. It is the very basis for every other right we enjoy as persons"7. The government for its part made it clear that no new rights were created and that they were legislating for $\mathrm{X}$ "because it is our duty as legislators to vindicate the rights of tens of thousands of women and their families". Nevertheless, inequality of treatment for suicidal women seeking termination has led pro-choice organizations to criticize the abortion legislation from the start. Johanna Westeson, regional director for Europe at the Centre for Reproductive Rights, has argued that this part of the bill "runs contradictory to international medical standards and human rights norms". Besides, she found that "to suggest that women would fake suicidal tendencies to access abortion is not only deeply offensive and misogynistic, but also in stark violation of women's human right to be treated with dignity". While it is clear that the issue is an interesting instance of the overlap between morality and law, it is no less clear that it is an illustration of conflicting understandings of human rights and human dignity.

4 Articles 40 to 44 of the 1937 Irish Constitution list the fundamental rights of Irish citizens. They are defined in extremely vague terms and few are explicitly mentioned. However, since Ryan $v$ Attorney general, courts have interpreted sections 1 and 2 of article $40^{10}$ to mean that they include "all those rights which result from the Christian and democratic nature of the State ${ }^{11}$ ". In one of his memos on Constitutional guarantees, Archbishop John Charles McQuaid himself noted: "The State guarantees to respect and defend the personal rights of each citizen, not only those that are inalienable, indefensible and antecedent to positive law, but also those that have been by law granted and defined ${ }^{12}$." In his opinion however, individual freedoms had to be understood as subservient to the "common good", that is to say the moral and social ideal promoted by the Catholic Church in the 1930s. In his comments on the directive principles of the Constitution he wrote: "A constitution is not a thesis of philosophy and theology. It is an enactment guided and 
delimitated by the teachings of Catholic philosophy and theology. It enshrines and sets forth the aim of what ought to be our Christian endeavour in social policy ${ }^{13}$." The preamble to the Constitution must be understood in that perspective. In the name of the Holy Trinity it pledges the Irish State to seek "to promote the common good, with due observance of Prudence, Justice and Charity, so that the dignity and freedom of the individual may be assured" and "true social order attained". As early as 1940, the Supreme Court ruled that "there is nothing in this clause of the Preamble which could be invoked to necessitate the sacrifice of the common good in the interests of the freedom of the individual ${ }^{14}$."

5 The insistence on the common good as opposed to individual rights was strongly reminiscent of papal statements going back to Pius IX. In Quanta Cura, an encyclical letter he issued in 1864 to condemn "current errors", he denounced States that did not "fear to foster that erroneous opinion, most fatal in its effects on the Catholic Church and the salvation of souls, [...] that a right resides in the citizens to an absolute liberty, which should be restrained by no authority whether ecclesiastical or civil [...] ${ }^{15 "}$. The context of the 1930s, as exemplified, for instance, in Casti Connubii, Pius XI's encyclical on Christian marriage, also had an easily identifiable bearing on the Constitution. McQuaid's view that "the aim of the State is to secure a social order, according to natural law and Christian teaching ${ }^{16}$ " is a key to understanding his and the early Irish State's stance on individual rights. Interestingly, it is also relevant in view of the contemporary debate since the International Theological Commission recently published a document entitled In Search of a Universal Ethic: A New Look at the Natural Law ${ }^{17}$ as a response to what the Church perceives as today's excessive ethical relativism.

\section{The natural law and Catholic teachings}

6 Writing about faith and culture in the Irish context in 1996, Eoin Cassidy noted: "It is ironic that the Catholic Church could be perceived as intrinsically hostile to individual liberty, considering that it is founded on the belief that all are created equal in the sight of God and that all share the dignity of unique individuals, free and responsible before God ${ }^{18}$." While this is undeniably true, the perception of human nature based on natural law, set in the context of a theory of salvation, contradicts the liberal understanding of human liberty. According to the Thomist interpretation of natural law, which became central to Catholic teaching essentially from the 1860s, the person is defined both as a free rational ontological being enjoying a privileged relationship with the deity, and as a being whose freedom is predetermined and limited by his nature. If men are fundamentally social by nature, "the concept of natural law presupposes the idea that nature is for man the bearer of an ethical message and is an implicit moral norm that human reason actualizes ${ }^{19}$ ". It is also claimed that man is spontaneously moral and naturally tries his utmost to do good and avoid evil.

7 The law of nature is presented as objective and universally binding, even if it is explicitly based on the Christian interpretation of God's will and part of His law. It concerns believers and non-believers alike, and from the $19^{\text {th }}$ century onwards, it was used to legitimize not only Church control on people's behaviour but on State legislation. Indeed Libertas Praestantissimum, Leo XIII's 1888 encyclical, decreed the superiority of the law of nature and the eternal law over human law. In this perspective, the function of the civil legislator was perceived as the duty "to keep the community in obedience by the adoption of a common discipline and by putting restraint upon refractory and viciously inclined men, so that, deterred from evil, they may turn to what is good $[. . .]^{20 "}$. Since then, the law of nature has been a constant reference in matters relating to the rights and 
duties of man (as for instance in John XXIII's Pacem in Terris, 1963) and sexuality (as, for instance in Pius XI's Casti Connubii, 1930 or Paul VI's Humanae Vitae, 1968). The latest version of the Catechism of the Catholic Church (1992) and John Paul II's Veritatis Splendor (1993) also stress the centrality of the law of nature in Catholic doctrine ${ }^{21}$. Its reaffirmation in 2009 only confirms this trend.

In order to understand the nature of the Church's message, it may be necessary to remember that the central precepts of the natural law reflect and derive from what the Church sees as the "three great sets of natural dynamisms that are at work in the human person", that is to say "the inclination to preserve and to develop one's own existence", "the inclination to reproduce, in order to perpetuate the species" and "the inclination to know the truth about God and to live in society ${ }^{22 "}$. Catholic morality as relates to sexuality and procreation derives from the second of these:

The dynamism towards procreation is intrinsically linked to the natural inclination that leads man to woman and woman to man, a universal datum recognized in all societies. It is the same for the inclination to care for one's children and to educate them. These inclinations imply that the permanence of the union of man and woman, indeed even their mutual fidelity, are already values to pursue, even if they can only fully flourish in the spiritual order of interpersonal communion ${ }^{23}$.

In the same way, the superiority of the group over individual interest proceeds from the third inclination.

Today, the International Theological Commission acknowledges that the world view based on the natural law has lost ground and laments the denial of nature as understood in Christian tradition. According to their analysis, man has come "to understand himself more and more as a 'denatured animal', an anti-natural being who affirms himself to the extent to which he opposes himself to nature". "The principal result of these developments", they say, "has been the split of the real into three separate, indeed opposed spheres: nature, human subjectivity, and God" ${ }^{24}$. Even though the historicity of the natural law is admitted in their 2009 document, the central tenets of human morality are seen as unchanging because they derive from the unchanging nature of man.

11 Critics of that world view note that this version of the law of nature is only one among several natural law theories and certainly not the only bulwark against total moral relativism it claims to be. Besides, all such theories have raised so many objections that they have for the most part been rejected by modern philosophy. One may also denounce the inconsistency of the tradition in several areas ${ }^{25}$. In some instances, for example, human reason is presented as a guide towards the discovery of the natural law; it is so in Pius XII's encyclical Humani Generis (1950). But in other cases, as in Pius XI's encyclical Casti Connubii, human reason is deemed far too unreliable to achieve that end, which legitimizes the social and moral power of the infallible $\mathrm{Church}^{26}$, the indoctrination of children and the uncritical attachment to tradition. Talking of contraception and voluntary human sterilization, Desmond Clarke comments:

The immorality of artificial contraception, on the Church's view, depends exclusively on one consideration: that such methods of birth control contravene the Church's interpretation of God's intentions, insofar as these intentions are revealed in the unmodified course of natural fertility and infertility ${ }^{27}$.

The Scriptures have little to say on moral issues anyway, and what they do say has to be understood in the context in which they were elaborated. German theologian Hans Küng ${ }^{28}$ makes the point that the traditional hostility of the Catholic Church towards women and sexuality can legitimately be blamed on St Augustine's flawed interpretation of Adam's 
fall, based on a mistranslation of the Greek original of St Paul's Letter to Romans (5-12). Whereas Paul had written that men were sinners like Adam, Augustine understood they were sinners through Adam's transgression. In order to fight against the Pelagian heresy, which stressed men's free will, Augustine thus reinterpreted the theory of original sin in a sense that made it hereditary and sexually determined. Augustine's theology of sin mostly developed in the medieval Church and stands at the origin of the Church's ban on sexuality ${ }^{29}$. This ban however did not become total until the $19^{\text {th }}$ century when Pius IX defined the dogma of the Immaculate Conception (1854) and reaffirmed the Church's position on the Original Sin as elaborated by the Council of Trent. The consequences of this debate and decisions on the Irish Church are well known. Nevertheless, in this area as in several others, the divine origin of the Catholic dogma and of the natural law has been undermined by the statement of crude facts.

13 Finally, it is sufficient to state that the law of nature in its contemporary Catholic version doesn't clearly define good and evil, and that it doesn't discuss the connection between nature and moral norms, which can be a source of confusion when it comes to assessing what is moral and what is not.

At the time when the Catholic Church was trying to articulate its universal power on the basis of the natural law in the $19^{\text {th }}$ century, the rival liberal model was also gaining ground. Just like Christian ethics, it drew its inspiration from classical Greek philosophy but was shaped by Renaissance humanists and the philosophers of the Enlightenment who emancipated from Christian theology. Today humanism and religious moral theories underlie competing world views. Indeed, "humanism is the ethical outlook that says each individual is responsible for choosing his or her values and goals and working towards the latter in the light of the former, and is equally responsible for living considerately towards others"30. Grayling defines humanism further by saying:

Humanism is the concern to draw the best from, and make the best of, human life in the span of a human lifetime, in the real world [...]. This entails that humanism rejects religious claims about the source of morality and value. [...] It is not the same thing as either secularism or atheism, but it has natural links to both ${ }^{31}$.

Humanism is also connected to individualism and it upholds the defence of human rights. In his seminal analysis of the change in the we-I balance, Norbert Elias argues that in democratic societies, the development of modern States led to a progressive individualization of citizens and the progressive rejection of more traditional allegiances. In the present he identifies a direction "towards a more comprehensive and durable total integration of mankind ${ }^{32}$ ", exemplified by the fact that power is being transferred from a lower to a higher level. While it is clear that, in this new context, individual citizens have little chance of influencing events at the global level and may become the victims of international superstructures, they can also benefit from the development of the global ethos of human rights. Following two world wars and the Universal Declaration of Human Rights of 1948, new initiatives have been launched. Elias mentions Amnesty International, but the European Court of Human Rights also falls in the same category of institutions which bear witness to "the spread of responsibility among individuals for the fate of others far beyond the frontiers of their own country or continent ${ }^{33}$ ". The example of Ireland being induced to legislate on abortion as a result of international pressure on the request of individuals is indeed a sign of the times. It is also a sign that the State has eventually succeeded in going a step further in the emancipation process which started a few decades ago. 


\section{Church-State relations in Ireland (1922-2013): from natural law to humanism}

16 It may in fact be argued that the history of Church and State relations in Ireland is an interesting illustration of the conflict between the Catholic natural law theory and the liberal humanistic world view. It is a fascinating case study because the shift from one model to the other occurred within less than a century and because present developments may confirm the emergence of a third way.

By the time the Irish Free State came of age in the 1930s, it had fully embraced the Catholic ethos. In a draft memo on Church and State, John Charles McQuaid wrote:

The State acknowledges that the true religion is that established by Our Divine lord Jesus Christ Himself, Which he committed to His Church to protect and propagate, as the guardian and interpreter of true morality [...]

Further, the State acknowledges that the Church of Christ is a (perfect) society, having within itself full competence and sovereign authority, in respect for the spiritual good of men ${ }^{34}$.

The State which emerged from this close association sought to turn into apparent reality the dream of the moralist. The myth that Ireland had become a beacon of purity came into force. Referring to Freud and Foucault, both Tom Inglis ${ }^{35}$ and Diarmaid Ferriter note that "control of sex and sexual relations was central to the creation and maintenance of power and social order" ${ }^{36}$. It was also a means to the end of making the myth come true, or rather appear true. In his superb study of sex and society in modern Ireland, Ferriter convincingly argues that the angelic ideal never stopped sexual crimes of all kinds and that Irish society was much more aware of sexual realities than has so far been acknowledged. What appears particularly fascinating therefore is the way in which the mythifying process was implemented.

As is the rule with myth, the first aspect of the process took the shape of the denial of its own historical construction. This was indeed part of the Catholic tradition. Talking of "traditional teaching on the Catholic Church as 'the one true Church' with its divinely revealed 'deposit of faith"', theologian Seán Fagan as many others exposed the overemphasis that the institution placed on continuity to hide historical reality. But in Roland Barthes' analysis, the function of myth is precisely "to empty reality", to empty it of history and fill it with nature. "Myth is depoliticized speech [...]. It organizes a world which is without contradictions because it is without depth, a world wide open and wallowing in the evident, it establishes a blissful clarity: things appear to mean something by themselves ${ }^{37}$."

This necessarily involves lying, endorsing amnesia or cultivating ambiguity. That such practices still hold true today is exemplified by exemplified by Bishop Christopher Jones's January 2013 statement that "the Catholic Church has never taught that the life of a child in the womb should be preferred to that of the mother or the life of the mother to that of the child" 38 . The current teaching of the Catholic Church embodied in the Congregation for the Doctrine of the Faith's "Declaration on procured Abortion" explicitly excludes abortion even if it is a question of life and death for the mother on grounds that "no-one can exempt women [...] from what nature demands of them ${ }^{39}$ ". Yet the principle of double effect defined by Pius $\mathrm{XII}^{40}$ and acknowledged in the Eighth Amendment to the Irish Constitution, allows life-saving interventions on pregnant women that may lead to the 
unintended death of the child. Nevertheless ambiguity remains. The principle of double effect does not induce the delivery of non-viable babies, since life-saving abortions must be independent of the mother's pregnant condition. Therefore it could not have saved Savita Halappanavar. Besides, even in cases when the mother's condition is unrelated to her pregnancy, the situation is unclear. In 2010 Sister McBride, the administrator of an American Catholic hospital, was excommunicated for allowing an abortion on a woman suffering from heart disease, whose risk of mortality was "close to $100 \%{ }^{41}$ ".

From the point of view of humanism, accusations of inhumanity make sense in such contexts. However, if we follow Barthes' analysis, it is also the function of myth to remove "from things their human significance so as to make them signify a human insignificance ${ }^{42}$ ", which induces that dehumanization is part of the mythifying process. As is well known, the collusion between Church and State in Ireland led to dehumanization in two ways: first of all through the denial of the body and the subsequent rejection of the physical, sexual, realities of humanity; and second, through the inhumane treatment of all those who did not conform to the model. These people were condemned to exclusion, public indictment or containment. Cruelty towards the most vulnerable was also part of picture, as is well exemplified by the fate of those children born to unmarried mothers ${ }^{43}$, who were exported and actually sold to America with little consideration for their wellbeing other than assurances that they would be raised in the Catholic faith ${ }^{44}$.

In this system at its worst, upholding the myth implied submitting citizens to pre-given answers and intimidating them into accepting the undisputed authority of the Church. Families, schools and the State itself were made complicit in the indoctrination of children and the control of adults. The conspiracy of silence and cover up served the purpose of hiding the realities which were not in conformity with the ideals. Therefore the Carrigan report (1931), which outlined the prevalence of prostitution and uncovered extensive child sexual abuse, was never made public but led to a containment culture ${ }^{45}$. In the same way the reports of the past few years have amply demonstrated that child abuse was hushed for decades.

While most religious certainly acted out of good faith and genuinely laboured for the salvation of Irish souls, the obsession with power on the part of Church leaders is obvious. In Enough is Enough, Fintan O'Toole shows that far from offering services that the State was unable to provide, "the institutional Church consistently undermined state services, fought to limit their expansion and consistently put the maintenance of its own power ahead of the interests of vulnerable people" ${ }^{\text {"46 }}$. The Irish Church is no exception in this respect. Hans Küng, who has an inside knowledge of Vatican proceedings, denounces Rome's monopoly of truth and power. He emphasizes the fact that Paul VI's controversial encyclical Humanae Vitae (1968), which confirmed the Church's ban on contraception and sexuality outside procreation, had more to do with infallibility than sexuality. Pius XI could not possibly have made a mistake in his own encyclical Casti Connubii (1930) and therefore there was no option but to confirm his teaching ${ }^{47}$.

In one of his articles published in 2008, Redemptorist priest Tony Flannery wonders what Christ would think of the Church's interpretation of his message. He suggests he wouldn't be too keen on the theology and law and wouldn't "feel at home in the Vatican" 48 . Progressive religious in contemporary Ireland have repeatedly denounced excesses in the name of what they see as the true Christian message. They have called for a reappraisal of the institutional Church's authority by attempting to demythify and rehistoricize its power and teachings. Rome's adamant position on priests' celibacy and the ordination of 
women doesn't stand the test of history; nor does its attitude towards sexuality and the body. Irish Christian feminists, but also churchmen such as Donal Dorr, Mark Patrick Hederman or Seán Fagan among others, have insisted on the necessity to abandon traditional tenets based on the history of the Church, an all too human institution, rather than on the Scriptures. In Does Morality Change? Fagan also defends the view that morality should (and did) vary in different contexts. However, what successive popes have called "historicism" has persistently been condemned by popes as a false opinion overthrowing "the foundation of all truth and absolute law"49. It is explicit in Pius XII's encyclical Humani Generis (1950) or John Paul II's Faith and Reason (1998) ${ }^{50}$, for example. In 2004, the Irish Bishops' conference issued a doctrinal warning against Fagan's 1997 book on morality ${ }^{51}$. More recently, investigation into the Irish Church ordered by Pope Benedict XVI "encountered a certain tendency, not dominant but fairly widespread among priests, religious and laity, to hold theological opinions at variance with the teachings of the Magisterium" 52 . Both Seán Fagan and Tony Flannery have been silenced by the Congregation for the Doctrine of the Faith. The latter, one of the founders of the Association of Catholic Priests, defied the order to stay quiet in January 2013. He revealed that he had been "subjected to frightening procedures reminiscent of the Inquisition" and felt threatened with excommunication for his views on women's ordination, birth control, homosexuality, divorce and remarriage ${ }^{53}$.

Tony Flannery defends the view that an enlightened Catholicism should take shape. With regard to abortion, he openly supports the government's proposed legislation and condemns the statement of the four archbishops on the issue. He declared the following:

In this debate, it is essential to remember that the teaching of the Catholic Church on abortion still holds. It calls on us to respect the life of unborn children. However many people in this country no longer follow the teaching of the Catholic Church and it is the task of our politicians to legislate for all citizens ${ }^{54}$.

26 We may suggest that this attitude is in keeping with that of liberal secularized Ireland. Deputy Prime Minister Eamon Gilmore's response to the bishops' statement echoes this view. He said that while "the bishops were entitled to express their opinion", "the laws of this country are made by those of us who are elected by the people and charged with that responsibility ${ }^{55}$. He also explicitly condemned the Pope's reaction to the draft bill by stressing that women were entitled to "legal clarity about their situation where their life is at risk" and to "more than understanding and mercy" ${ }^{56 "}$. Times have definitely changed. In 1951, the Mother and Child Scheme was withdrawn following a statement by the Irish bishops. In those times, the natural law as understood by the Catholic Church was acknowledged as superior to civil law. The recent debate has shown that humanism has now superseded previous approaches. Saying as Eamon Gilmore did that "what the Pope was expressing was the long established and well known view of his ${ }^{57}$ church $^{58 "}$ only confirms the deterioration of the relationships between the Vatican and the State as well as the split between Church and State in Ireland itself.

What is striking, however, is that Christian values stand at the core of the State's claims. The Irish State has on several occasions apologized for its past tolerance towards the Church's inhuman treatment of the people in its care. In recent times, for example, Enda Kenny announced a compensation scheme for survivors of the Magdalene laundries, which he presented as the "nation's shame". He added that the matter would be dealt with as "comprehensively, sensitively and compassionately" as possible for the survivors 
59. It is striking that compassion and emotion should now be on the side of the State redressing the abuses of the Church.

If we are to believe the most recent census returns, Ireland remains strongly attached to the Catholic faith, but most people no longer respect the Church's teachings, particularly in the area of sexual morality. The third way that is currently being followed by the Irish State seems to indicate the strong influence of humanism, but without the latter's strong connection with atheism. A liberal form of Catholicism has been taking shape in recent years. It places humanity centre stage. Whilst the myth which prevailed in the early years of the Irish Free State dehumanized the public social and moral discourse, the new ethos seeks to re-humanize it. Politicians are not alone in their attempt. Progressive voices in the Church insist on the necessity to reintegrate the body and the "dark side" of each human being ${ }^{60}$ in order to conform to Christ's message of love. Donal Dorr calls for a theology of sexuality ${ }^{61}$, and even more moderate theologians, such as Gerry O'Hanlon ${ }^{62}$ or Vincent McNamara, insist on a "Call to be Human ${ }^{63}$ " within existing structures, if only by fully enforcing the decrees of Vatican II. The passage of Irenaeus' Against Heresies, which emphasizes that the glory of God is humanity fully alive ${ }^{64}$, is quoted at length to legitimize the new approach. However, the intensity of the debate on abortion is a sign that the two models analyzed in this paper are still alive and kicking in Ireland, just as they are in the rest of the world. The controversy over same sex marriage in France or the United States actually shows that traditional perspectives are not the privilege of States that have recently emerged from the control of the Catholic Church.

Dublin hosted the International Eucharistic Congress in 1932 and 2012. In 1932, both Church and State sought to "present Ireland as being the centre of a spiritual empire, presented as a morally superior counterweight to the British Empire ${ }^{65}$ ". Even though the 2012 edition was a great success, it came just a year after the Taoiseach's condemnation of "the dysfunction, the disconnection, the elitism that dominates the Vatican today" and his call for the expulsion of the papal nuncio. In the aftermath of the Cloyne report revelations, he had accused the Vatican of breaching the legal principle of noninterference in the internal affairs of sovereign States and behaving in a way which was "the polar opposite of the radicalism, the humility and the compassion upon which the Roman Church was founded". He had further insisted on the separation between Church and State by stating that Ireland was a "republic of laws, of rights and responsibilities, of proper civic order, where the delinquency and arrogance of a particular version of a particular kind of morality [would] no longer be tolerated or ignored ${ }^{66}$." The eighty years which elapsed between the two congresses witnessed the advent of a new world view and the first legal abortion in Ireland was carried out in August 2013. In the words of Gerry O'Hanlon, "God had promised to be with the Church always, to the end of times: this ignores the simple reality that God has not promised to be with the Church in Ireland till the end of time [...], and that, more importantly, God's promises always call forth a human response ${ }^{67}$. 


\section{NOTES}

1. July 2013.

2. Article 3 of the European Convention on Human Rights, Case A, B and C v Ireland, 2010, [ http://hudoc.echr.coe.int/sites/eng/pages/search.aspx?i=001-102332] (Accessed 2 June 2013). The European Court of Human Rights eventually dismissed this allegation as ill founded, but ruled that Ireland did violate articles 8 (right to respect for private and family life) and 14 (prohibition of discrimination ) of the convention. It recommended that Ireland clarify the law as to the rights of pregnant women seeking termination when their life is threatened. The Council of Europe then urged the Irish government to implement the judgment. The Irish government appointed an expert group which issued its report in November 2012.

3. Desmond Clarke, Church and State: Essays in Political Philosophy, Cork,CUP, 1984, p.168.

4. Ibid.

5. Ibid. p. 169.

6. The Regulation of Information (Services outside the State for Termination of Pregnancies) Act 1995 ("the 1995 Act") was the government's first step in this direction.

7. Irish Catholic Bishops' Conference, "Statement by the four Archbishops of Ireland in response to the decision today by the Government to legislate for abortion", [http:// www.catholicbishops.ie/2012/12/18/statement-archbishops-ireland-response-decisiontoday-government-legislate-abortion/] (accessed 25/05/2013).

8. Arthur Beesley and Paul Cullen, « Kenny stresses law on abortion not being altered", The Irish Times, 2 May 2013, [http://www.irishtimes.com/news/health/kenny-stresseslaw-on-abortion-not-being-altered-1.1379264] (accessed 25/05/2013).

9. Henry McDonald, "Irish Abortion Bill accused of being misogynistic and offensive", The Guardian, 1 May 2013, [http://www.guardian.co.uk/world/2013/may/01/irish-abortionbill-misogynistic-offensive] (accessed 25/05/3013).

10. "Art. 40.1 - The State guarantees in its laws to respect, and as far as practicable, by its laws to defend and vindicate the rights of citizens

Art. 40.2 - The State shall, in particular, by its laws protect as best it may from unjust attack, in the case of injustice done, vindicate the life, person, good name, and property rights of every citizen". Bunreacht na hÉireann, [www.constitution.org/cons/ireland/ constitution_ireland-en.htm] (accessed 25/05/2013).

11. Ryan v. Attorney General (1965) I.R., 294 at p. 312; quoted by Desmond Clarke, op. cit., p.137.

12. Clara Cullen and Margaret Ó hógartaigh (eds), His Grace Is Displeased - Selected Correspondence of John Charles McQuaid, Dublin, Merrion, 2013, p. 11.

13. Ibid. p. 10.

14. In re Article 26 of the Constitution and the Offences against the State (Amendment) Bill 1940,

I.R. 470 at p.481; quoted by Desmond Clarke, op. cit., p. 153. 
15. Pius IX, Quanta Cura, 1864, [http://www.papalencyclicals.net/Pius09/p9quanta.htm] (accessed 25/05/2013).

16. Letter from John Charles McQuaid to Éamon de Valera, 8 October 1939, in Clara Cullen and Margaret Ó hógartaigh, His Grace Is Displeased, op. cit. p. 26.

17. International Theological Commission, In Search of a Universal Ethic: A New Look at the Natural Law, 2009, [ http://www.vatican.va/roman_curia/congregations/cfaith/ cti_documents/rc_con_cfaith_doc_20090520_legge-naturale_en.html] (Accessed 25/05/2013)

18. Eoin Cassidy, «Religion and Culture: the Freedom to be an Individual", in Eoin Cassidy (ed), Faith and Culture in the Irish Context, Dublin, Veritas, 1996, p. 63.

19. Ibid. p. 69.

20. Leo XIII, Libertas Praestantissimum, 1888, section 9, [http://www.vatican.va/ holy_father/leo_xiii/encyclicals/documents/hf_l-xiii_enc_20061888_libertas_en.html] (Accessed 26/05/2013).

21. Commission théologique internationale, A la recherche d'une éthique universelle Nouveau regard sur la loi naturelle, Paris, Cerf, 2009, p. 57-8.

22. International Theological Commission, op. cit. 2.3-46.

23. Ibid. 2.4-49.

24. Ibid. 3.3-71.

25. Desmond Clarke, op. cit. p. 61 and p. 48-60.

26. Pius XI, Casti Connubii, 1930, [ http://www.vatican.va/holy_father/pius_xi/ encyclicals/documents/hf_p-xi_enc_31121930_casti-connubii_en.html] (accessed 26/05/2013).

27. Desmond Clarke, op. cit. p. 65.

28. Hans Küng was originally a friend of Josef Ratzinger, with whom he was involved in the Council Vatican II as expert.

29. Hans Küng, Peut-on encore sauver l'Eglise, Paris, Seuil (2011) 2012, p. 91-3.

30. Anthony Grayling, The God Argument - The Case against Religion and for Humanism, London, New Delhi, New York, Sydney, Bloomsbury, 2013, p.139.

31. Ibid. p.140.

32. Norbert Elias, The Society of Individuals, 1987, p. 176, [ http://www.revalvaatio.org/wp/ wp-content/uploads/elias-the_society_of_individuals.pdf] (accessed 26/05/2013).

33. Ibid. p.179.

34. Clara Cullen and Margaret ó hógartaigh (eds), op. cit. p.22.

35. Tom Inglis, Lessons in Irish Sexuality, Dublin, UCD Press, 1998, p. 15-6 and 92.

36. Diarmaid Ferriter, Occasions of Sin - Sex and Society in Modern Ireland, London, Profile Books, (2009) 2012, p.19.

37. Roland Barthes, Mythologies, Paris, Seuil, 1957, p. 230. This translation: [http:// xroads.virginia.edu/ drbr/myth.html] (accessed 29 May 2013).

38. "Catholic Church calls on government to hold abortion referendum" (anonymous), Irish Examiner, 10 January 2013, [http://www.irishexaminer.com/breakingnews/ireland/ catholic-church-calls-on-government-to-hold-abortion-referendum-580659.html]

(accessed 29 May 2013). 
39. Congregation for the Doctrine of the Faith, "Declaration on Procured Abortion", 1974, section 14, [http://www.vatican.va/roman_curia/congregations/cfaith/documents/ rc_con_cfaith_doc_19741118_declaration-abortion_en.html] (accessed 29 May 2013). See also the series of articles on the issue of abortion republished in Enda McDonagh and Vincent McNamara (eds), An Irish reader in Moral Theology - the Legacy of the last Fifty Years, Vol. 3 Medical and Bio Ethics, Dublin: The Columba Press, 2013, p. 95-166.

40. It makes indirect abortion admissible. Pius XII, "Address to the Family Front Congress", 27 November 1951, in AAS 43 (1951) p. 857-859.

41. Barbara Bradley Hagerty, "Nun Excommunicated For Allowing Abortion", National Public Radio 19 May 2010, [ http://www.npr.org/templates/story/story.php? storyId $=126985072]$.

42. Roland Barthes, Mythologies, op. cit. p. 230. This translation: [

http://xroads.virginia.edu $\sim$ DRBR/myth.htm] (accessed 29 May 2013).

43. According to the Carrigan Report (1931), illegitimacy was evil.

44. Mike Milotte, Banished Babies - The Secret History of Ireland's Baby Export Business, Dublin, New Island, (1997) 2012.

45. James Smith, "The Origins of Ireland's Containment Culture and the Carrigan Report", in Journal of the History of Sexuality, 13-2, 2004, p. 208-33, [http://www.jstor.org/ discover $/ 10.2307 / 3704856$ ?

uid=3738016\&uid=2129\&uid=2\&uid=70\&uid=4\&sid=21102065034743], accessed 2 June 2013).

46. Fintan O'Toole, Enough is Enough - How to build a New Republic, London, Faber and Faber, 2011, p. 97.

47. Hans Küng, op. cit., p. 119-20.

48. Tony Flannery, "A not so gentle Jesus ", in Fragments of Reality - Collected Writings, Dublin, The Columba Press, 2008, p. 85-6.

49. Pius XII, Humani Generis, section 7, [http://www.vatican.va/holy_father/pius_xii/ encyclicals/documents/hf_p-xii_enc_12081950_humani-generis_en.html] (accessed 1 June 2013).

50. In John Paul II's view, historicism is one of several contemporary errors, including relativism and biblicism John Paul II, which are necessarily connected with historicism. Faith and Reason, Chapter V, paragraph 54, http://www.vatican.va/holy_father/ john_paul_ii/encyclicals/documents/hf_jp-ii_enc_15101998_fides-et-ratio_en.html] (Accessed 1 June 2013).

51. "Irish Bishops Critical of Book on Moral Theology" (anonymous), Catholic News, 6 August 2004, [http://cathnews.acu.edu.au/408/36.php] (accessed 1 June 2013).

52. David Kerr, «Apostolic Visitation calls for Overhaul of Church in Ireland", Catholic News Agency, 20 March 2012, [http://www.catholicnewsagency.com/news/apostolicvisitation-calls-for-overhaul-of-church-in-ireland/] (accessed 2 June 2013).

53. Association of Catholic Priests, Tony Flannery is threatened with excommunication, [http://www.associationofcatholicpriests.ie/2013/01/press-release-on-behalf-of-tonyflannery/] ,cessed 9 February 2014 
54. Tony Flannery, « Catholic Bishops made five Mistakes in their Opposition to Abortion Legislation", The Journal.ie, 5 May 2013, [http://www.thejournal.ie/readme/column-tonyflannery-catholic-church-abortion-897260-May2013/] (accessed 2 June 2013).

55. Douglas Dalby, «Irish Catholic Church Condemns Abortion Legislation, 3 May 2010 ", New York Times, 3 May 2013.

56. Fionnan Sheahan, « Gilmore disagress with Pope on Abortion Laws", Irish Independent, 8 January 2013, [http://www.independent.ie/irish-news/gilmore-disagrees-with-popeon-abortion-laws-28955846.html] (accessed 2 June 2013).

57. My emphasis.

58. Fionnan Sheahan, « Gilmore disagress with Pope on Abortion Laws", op. cit.

59. « Kenny vows Compassionate Redress » (anonymous), Irish Independent, 20 February 2013, [http://www.independent.ie/irish-news/kenny-vows-compassionateredress-29084248.html] (accessed 2 June 2013).

60. Mark Patrick Hederman, Kissing the Dark, Dublin, Veritas, 1999.

61. Donal Dorr, Time for a Change, Dublin, The Columba Press, 2004.

62. Gerry O'Hanlon S.J., A New Vision for the Catholic Church: A View from Ireland, Dublin, The Columba Press, 2011.

63. Vincent McNamara, The Call to be Human - Making Sense of Morality, Dublin, Veritas, 2010.

64. Irenaeus, Against Heresies 4.34.5-7.

65. John Paul McCarthy and Tomás O’Riordain, “The $31^{\text {st }}$ International Congress, Dublin 1932", UCC multitext project in Irish History, [http://multitext.ucc.ie/d/ The_31st_International_Eucharistic_Congress_Dublin_1932] (accessed 2 June 2013).

66. "Kenny condemns the 'dysfunction and disconnection' of the Catholic Church" (anonymous), The Journal.ie, 20 July 2011, [http://www.thejournal.ie/kenny-condemnsthe-dysfunction-and-disconnection-of-the-catholic-church-182356-Jul2011/] (accessed 2 June 2013).

67. Gerry O'Hanlon S.J., op. cit. p. 64.

\section{ABSTRACTS}

The 2013 debate on abortion is the starting point of this paper, which argues that the evolution of Church-State relationships since the creation of the Irish Free State may be understood in theological and philosophical terms. The traditional world view based on the natural law has indeed progressively been superseded by a more and more humanistic framework of ideas and beliefs. However, both viewpoints still attract support today, which leads to misunderstandings and necessarily intractable conflicts.

Partant de l'analyse du débat de 2013 sur la législation relative à l'avortement, cet article défend l'idée que l'évolution des relations entre l'Etat et l'Eglise en Irlande depuis la création de l'Etat 
libre peut se comprendre en termes théologiques et philosophiques par le passage d'un mode de représentation majoritaire fondé sur la loi naturelle à une vision du monde de plus en plus nettement humaniste. Les deux modèles coexistent toutefois encore aujourd'hui et les incompréhensions qui résultent de leurs confrontations aboutissent à des conflits nécessairement insolubles.

INDEX

Keywords: human rights, Irish Catholic Church, Irish State (Republic of Ireland), society and religion, theology

Mots-clés: droits humains, État irlandais (République d'Irlande), société et religion, Église catholique d'Irlande, théologie

\section{AUTHOR}

\section{CATHERINE MAIGNANT}

Université Lille 3 